\title{
Crossreaction of antilymphocyte globulin with human granulocyte colony-forming cells
}

\author{
A. J. BARRETT, P. LONGHURST, N. ROSENGURT, J. R. HOBBS, AND \\ J. G. HUMBLE
}

From the Departments of Haematology and Chemical Pathology, Westminster Medical School, and the Tissue Typing Department, Westminster Hospital, London SWIP 2AP, UK

SUMMARY Clinical preparations of horse antilymphocyte globulin(ALG) were found to inhibithuman bone marrow granulocyte colony growth. This effect was enhanced by complement and was dose dependent, being almost complete at ALG concentrations of $100 \mu \mathrm{g} / \mathrm{ml}$. Inhibition was a property of ALG but not of normal horse globulin. However, short incubation of ALG with bone marrow cells occasionally stimulated colony growth and normal horse globulin regularly stimulated it. Three hours' incubation of bone marrow cells with ALG was needed to produce consistent colony inhibition, which was measurable as a reduction in the expected number of colonies and as a fall in the colony:cluster ratio of surviving cell aggregates. Absorption of ALG on acute myeloid leukaemia blast cells removed the inhibiting property of the ALG while preserving its lymphocytotoxic action. Serum from two patients receiving ALG treatment inhibited colony growth for up to 48 hours after ALG administration. The results suggest the presence in ALG of antibodies specifically cytotoxic to myeloid stem cells which may relate to its myelosuppressive properties in vivo, and also indicate that it should be possible to remove antimyeloid antibodies from ALG by absorption. The use of such purified ALG would have advantages in clinical bone marrow transplantation.

Antilymphocyte globulin (ALG) and antithymocyte globulin (ATG) inhibit human granulocyte colony growth (Rodt et al., 1974; Barrett et al., 1975). There is evidence from animal experiments that ALG also inactivates bone marrow stem cells in vivo and in vitro (Field and Gibbs, 1968; DeMeester et al., 1968), and ALG and ATG have occasionally been implicated in the failure of bone marrow transplants to establish a graft in patients with aplastic anaemia (Storb et al., 1974; Barrett et al., 1975). We have investigated (1) the inhibition of human granulocyte colony-forming cells (CFU) by ALG, (2) methods to remove this inhibition, and (3) the cliuical relevance of this interaction.

\section{Material and methods}

The ALG preparations tested are shown in Table 1. All globulins were purified and preliminarily absorbed by the manufacturer for clinical use.

Received for publication 28 July 1977
Table 1 Globulin preparations tested

\begin{tabular}{lll}
\hline Designation & Manufacturer & Batch No. \\
\hline ALG 1 & Burroughs Wellcome & TD4 \\
ALG 2 & Hoechst & 514 \\
ALG 3 & Hoechst & 509 \\
ALG 4 & Hoechst & 817027 \\
ALG 5 & Hoechst & 0288 \\
ALG 6 & Hoechst & 070170 \\
ALG 7 & Hoechst & 506 \\
NHG (normal horse & Hoechst & 161097 \\
globulin) & & \\
\hline
\end{tabular}

INCUBATION OF BONE MARROW CELLS WITH ALG

Human bone marrow was obtained from diagnostic aspirates of haematologically normal patients or from bone marrow obtained from the donor during marrow transplantation. Bone marrow was aspirated into preservative-free heparin $(20 \mathrm{iU} / \mathrm{ml})$ and the buffy coat obtained after sedimentation for $1 \frac{1}{2}$ hours at $37^{\circ} \mathrm{C}$. The cells were washed twice and resuspended in $\mathrm{McCoy}$ 5A medium. The nucleated cells were 
counted and the volume of the cell suspension was adjusted to obtain $10^{6} \mathrm{cells} / \mathrm{ml}: 0.7 \mathrm{ml}$ volumes of this suspension were pipetted into sterile tubes containing either $0 \cdot 1 \mathrm{ml}$ normal horse globulin (NHG) or ALG in final concentrations varying from 100 to $0.1 \mu \mathrm{g} / \mathrm{ml}: 0.2 \mathrm{ml}$ of fresh autologous serum was added to each tube. In some experiments duplicate tubes were prepared with autologous serum heated to $56^{\circ} \mathrm{C}$ for 30 minutes to inactivate complement. A control tube containing $0.2 \mathrm{ml}$ serum but no horse globulin was also prepared for each experiment. The cells were incubated at $37^{\circ} \mathrm{C}$ for varying periods of time in different experiments. They were then washed twice in McCoy 5A medium containing $15 \%$ fetal calf serum or human $\mathrm{AB}$ serum and put into culture.

\section{GRANULOCYTE COLONY CULTURE}

Colony culture followed the technique described by Pike and Robinson (1970), but in later experiments $15 \%$ human $\mathrm{AB}$ serum was used in place of fetal calf serum since it was found to support colony growth better. The washed cell buttons obtained by centrifugation after incubation with globulin were resuspended in $3.5 \mathrm{ml}$ of $0.3 \%$ agar and medium and $1-\mathrm{ml}$ volumes were pipetted into triplicate culture dishes on blood leucocyte feeder layers in $0.5 \%$ agar prepared at least four days in advance to avoid interference of any residual ALG with colony-stimulating factor production by the feeder layer.

Colonies were counted after 12 to 14 days' incubation at $37^{\circ} \mathrm{C}$ in $7.5 \% \mathrm{CO}_{2}$ and scored as cell groups of 40 or more. Clusters (groups of 5-39 cells) were counted separately. Results were expressed as mean \pm standard deviation for triplicate samples.

ABSORPTION OF ALG 2

Chronic lymphatic leukaemia (CLL) cells were obtained from an untreated patient by separation of lymphocytes on Lymphoprep (Nygaard Ltd). This preparation contained over $99 \%$ lymphocytes.

Chronic granulocytic leukaemia (CGL) cells were obtained from an untreated patient with Philadelphia chromosome positive CGL whose leucocyte count was $200 \times 10^{9} / 1$, with $1 \%$ lymphocytes and $4 \%$ myeloblasts.

Acute myeloid leukaemia (AML) blast cells were obtained by kind permission of Dr R. Powles from an untreated patient undergoing leucopheresis. This preparation was preserved at $-70^{\circ} \mathrm{C}$ in dimethyl sulphoxide. It contained over $99 \%$ myeloblasts and no lymphocytes.

ALG 2 was absorbed overnight on washed preparations of packed cells in the ratio of $1 \mathrm{mg}$ of globulin to $10^{8}$ cells. The mixture was resuspended and incubated for a further hour before centrifugation at $600 \mathrm{~g}$. The clear supernatant was then removed for testing. Using packed leucocytes the volume of globulin before and after absorption did not alter significantly, and absorbed globulin was diluted identically with the unabsorbed globulin for testing at concentrations of 100,10 , and $1.0 \mu \mathrm{g} / \mathrm{ml}$.

\section{LYMPHOCYTOTOXICITY TESTS}

ALG was tested for lymphocytotoxicity by the Terasaki two-step method in microtoxicity plates. Of each globulin dilution $1 \mu \mathrm{l}$ was added to $2 \mu \mathrm{l}$ of lymphocytes obtained from normal individuals and incubated for $\frac{1}{2}$ hour before adding rabbit complement. The cells were incubated for a further $1 \frac{1}{2}$ hours. Eosin was then added and cytotoxicity assessed using an inverted objective microscope. The globulin was tested absorbed and unabsorbed at final concentrations of 100,10 , and $1 \mu \mathrm{g} / \mathrm{ml}$ on lymphocytes from normal subjects. Results were expressed as the mean lymphocytotoxicity for four experiments using a different lymphocyte donor on each occasion.

\section{TESTS USING SERUM OF PATIENTS TREATED} WITH ALG

Two patients were given $40 \mathrm{mg} / \mathrm{kg} /$ day of ALG 2 for five days by intravenous infusion during treatment for pure red cell aplasia (case A) and severe aplastic anaemia (case B). Blood was taken before, during, and after ALG administration; serum was separated and stored at $-40^{\circ} \mathrm{C}$ and tested for colony-inhibiting properties on a single bone marrow sample. $10^{6}$ nucleated cells in $0.7 \mathrm{ml}$ were incubated for two hours at $37^{\circ} \mathrm{C}$ with $0.2 \mathrm{ml}$ volumes of patients' serum and $0.1 \mathrm{ml}$ of fresh $A B$ serum and the cells were then washed and put into culture.

\section{Results}

EFFECT OF COMPLEMENT AND

COMPARISON OF ALG WITH NORMAL HORSE GLOBULIN

A preliminary experiment showed that ALG 1 을 inhibited colony growth in a dose-dependent manner and that the effect was enhanced by fresh autologous serum used as a source of complement (Fig. 1).

The results of three similar experiments are shown in Table 2. Inhibition was greater in the presence of a source of complement, but this difference was 0 reproducibly significant only for concentrations of globulin of $100 \mu \mathrm{g} / \mathrm{ml}$.

ALG in the absence of complement showed sig nificant inhibition only when compared with NHG at concentrations down to $10 \mu \mathrm{g} / \mathrm{ml}$, while the addition of complement produced significant inhibition at concentrations as low as $1 \mu \mathrm{g} / \mathrm{ml}$. 
Table 2 Effect of $A L G$ and NHG in three similar experiments after marrow was incubated with serum for two hours. Figures indicate percentage of control colony grow'th incubated without added globulin

\begin{tabular}{lrrrr}
\hline Experiment & \multicolumn{5}{c}{ Globulin concentration $(\mu \mathrm{g} / \mathrm{ml})$} \\
\cline { 2 - 5 } & $0 \cdot 1$ & 1 & 10 & 100 \\
\hline ALG + complement & 60 & 43 & 36 & 8 \\
& 54 & 48 & 45 & 35 \\
ALG, no complement & 100 & 75 & 91 & 37 \\
& 94 & 92 & 46 & 22 \\
NHG + complement & 51 & 112 & 66 & 51 \\
& 80 & 77 & 85 & 77 \\
& 82 & 82 & 97 & 134 \\
& 131 & 131 & 138 & 127
\end{tabular}

Significance of differences $(\mathrm{P})$

NHG $v$ ALG

NHG $v$ ALG + complement NS

ALG + complement $v$ ALG, NS

no complement

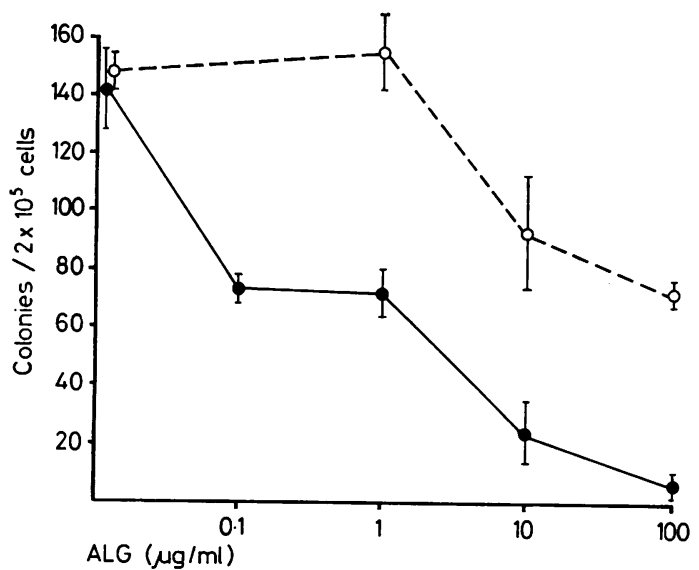

Fig. 1 Experiment showing dose-dependent inhibition of colonies by ALG. Without added complement - - -, with complement -. Cells were incubated with ALG and $10 \%$ fresh autologous serum as a source of complement for two hours.

EFFECT OF NHG

NHG tended to stimulate colony growth in a dosedependent manner and never showed dose-dependent inhibition.

\section{DURATION OF INCUBATION}

Repeated experiments where ALG 1 was incubated with bone marrow cells for one to two hours produced considerable variation in the amount of inhibition. Occasionally ALG stimulated colony growth (Fig. 2). Experiments where the incubation time of ALG with marrow cells was varied were carried out (Table 3 ). In experiment A exposure of cells for five minutes to NHG and ALG produced an increase in colony numbers compared with the control, which diminished after $1 \frac{1}{2}$ hours' incubation with ALG but persisted with NHG. In experiment B ALG and NHG stimulated colony growth initially but after three hours the ALG showed inhibitory properties.

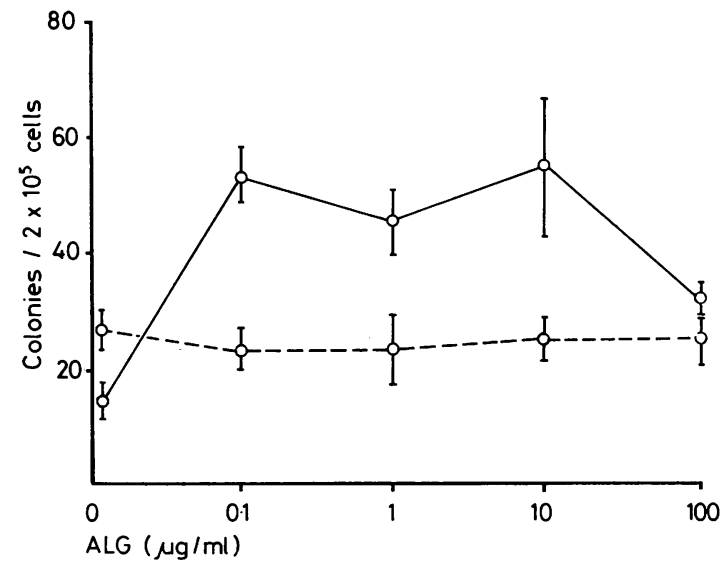

Fig. 2 Experiment showing stimulation of colony growth by $A L G$ after incubation of bone marrow with $A L G$ and complement for one hour. - Complement added, - - no complement $(10 \%$ fresh autologous serum was used as complement).

Table 3 Two experiments in which bone marrow was incubated with ALG or NHG for varying periods of time before being put into culture

\begin{tabular}{|c|c|c|c|}
\hline \multirow{2}{*}{$\begin{array}{l}\text { Duration of } \\
\text { incubation }\end{array}$} & \multicolumn{3}{|c|}{ Colonies $/ 2 \times 10^{5}$ cells $($ mean $\pm S D)$} \\
\hline & $\begin{array}{l}A L G 1 \\
(10 \mu g / m l)\end{array}$ & $\begin{array}{l}N H G \\
(10 \mu \mathrm{g} / \mathrm{ml})\end{array}$ & $\begin{array}{l}\text { Control } \\
\text { (no globulin) }\end{array}$ \\
\hline $\begin{array}{c}\text { Experiment } A \\
5 \mathrm{~min} \\
100 \mathrm{~min}\end{array}$ & $\begin{array}{l}25 \pm 4 \cdot 5 \\
11 \pm 4\end{array}$ & $\begin{array}{l}23 \pm 5 \\
27 \pm 3 \cdot 5\end{array}$ & $\begin{array}{l}10.6 \pm 3 \\
-\end{array}$ \\
\hline $\begin{array}{c}\text { Experiment } B \\
\begin{array}{cl}1 \frac{1}{2} & h \\
3 & h \\
6 & h \\
18 & h\end{array}\end{array}$ & $\begin{array}{c}162 \pm 9 \cdot 5 \\
117 \pm 5 \cdot 5 \\
61 \pm 12 \\
79 \pm 8\end{array}$ & $\begin{array}{l}187 \pm 2 \cdot 5 \\
138 \pm 6 \\
101 \pm 9 \cdot 5 \\
100 \pm 11\end{array}$ & $\begin{aligned} 137 & \pm 9 \\
142 & \pm 4 \\
112 & \pm 4 \\
92 & \pm 8.5\end{aligned}$ \\
\hline
\end{tabular}

COLONY INHIBITION ASSAY

After these results further studies were carried out in conditions designed to produce optimum ALGmediated colony inhibition. Bone marrow cells were incubated for three hours at $37^{\circ} \mathrm{C}$ in the presence of complement before being washed and put into culture. Two identical experiments were carried out to test the colony-inhibiting properties of six ALGs. 
The mean results of these two experiments are shown in Figure 3. All preparations showed inhibition; only one (ALG 7) was significantly less inhibitory and NHG did not cause dose-dependent inhibition. Analysis of the colony:cluster ratio in these experiments showed a close correlation between the degree of inhibition observed and the fall in the colony: cluster ratio ( $r=0.96 ; P=0.001$, Fig. 4).

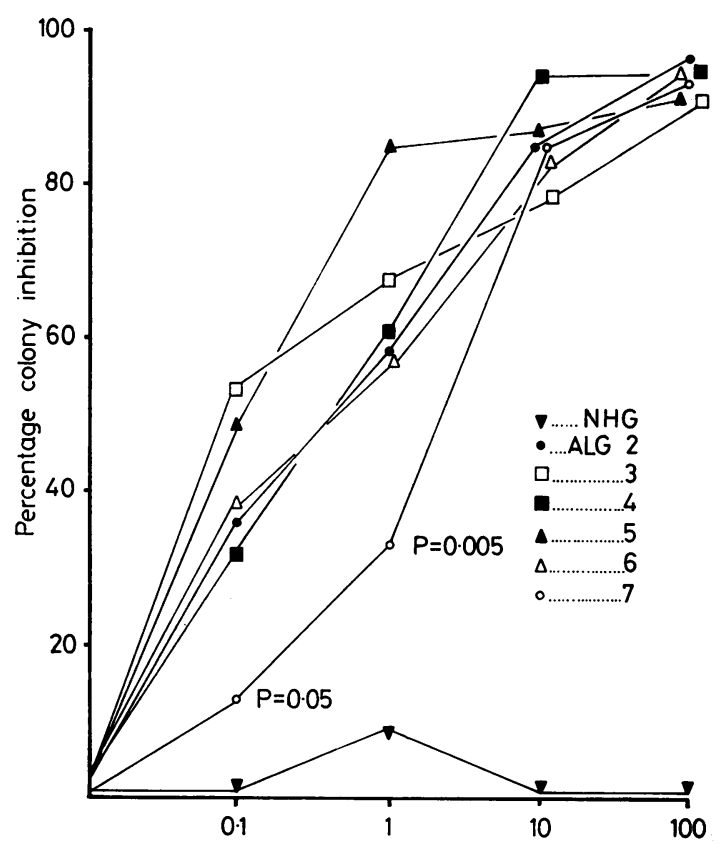

ALG $(\mu \mathrm{g} / \mathrm{ml})$

Fig. 3 Colony inhibition by ALG 2-7 after three hours' incubation in presence of complement. ALG 7 was significantly less inhibitory than the other preparations.

\section{ABSORPTION OF ALG}

The results obtained with ALG in single absorption on AML, CLL, or CGL cells are shown in Figure 5. Lymphocytotoxicity and colony inhibition of these preparations are compared. AML absorption did not modify lymphocytotoxicity but almost completely removed colony inhibition. A further single absorption of ALG on AML cells was carried out using $10^{7} \mathrm{cells} / \mathrm{mg}$ of globulin, which showed that at least $10^{8}$ cells $/ \mathrm{mg}$ were required effectively to remove anticolony activity but that a single absorption with this number of cells was satisfactory. CLL absorption greatly reduced lymphocytotoxicity without removing anticolony activity, while CGL cells produced reduction in lymphocytotoxicity and colony inhibition.
COLONY INHIBITION IN SERUM OF PATIENTS TREATED WITH ALG

Serum from two patients during ALG administration inhibited colony growth after $\mathbf{4 8}$ hours (case B) and after 24 hours (case A). Serum taken before ALG administration did not inhibit colony growth when compared with a control (autologous) serum (Table 4).

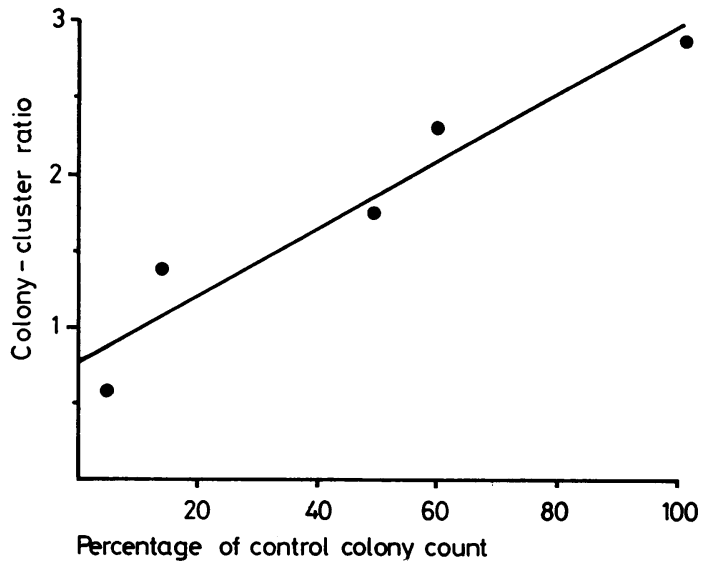

Fig. 4 Relationship of colony inhibition to colony: cluster ratio. Each point represents the mean results of values for ALG 2-7 on a single bone marrow sample. $r=0.96 . \mathrm{P}=0.001$.

Table 4 Colony inhibition in serum of patients undergoing treatment with ALG 2. Normal bone marrow cells were incubated for two hours in presence of $20 \%$ patient's serum and $10 \%$ fresh AB serum before being put into culture

\begin{tabular}{lc}
\hline Relationship to ALG treatment & Colonies $/ 2 \times 10^{5}$ cells $($ mean $\pm S D)$ \\
\hline Case $A$ & \\
Before treatment & $11 \cdot 3 \pm 2.8$ \\
During first infusion & $5 \cdot 0 \pm 0.7$ \\
18 hours after infusion & $2 \cdot 5 \pm 0.7$ \\
48 hours after infusion & $2 \cdot 0 \pm 0.7$ \\
Case B & $11.3 \pm 0.6$ \\
Before treatment & $4.5 \pm 0.7$ \\
21 hours after infusion & $8.0 \pm-7$ \\
48 hours after infusion & $14.6 \pm 3.2$ \\
4 days after infusion & $12.5 \pm 3.0$ \\
Control & \\
Autologous serum & \\
\hline
\end{tabular}

\section{Discussion}

The variable results obtained after short exposure of bone marrow cells to ALG may be explained by opposing properties of horse ALG, which showed an immediate stimulating action with NHG but also a slower inhibiting effect on CFU. The mechanism of this stimulating action is not clear. It may be the 

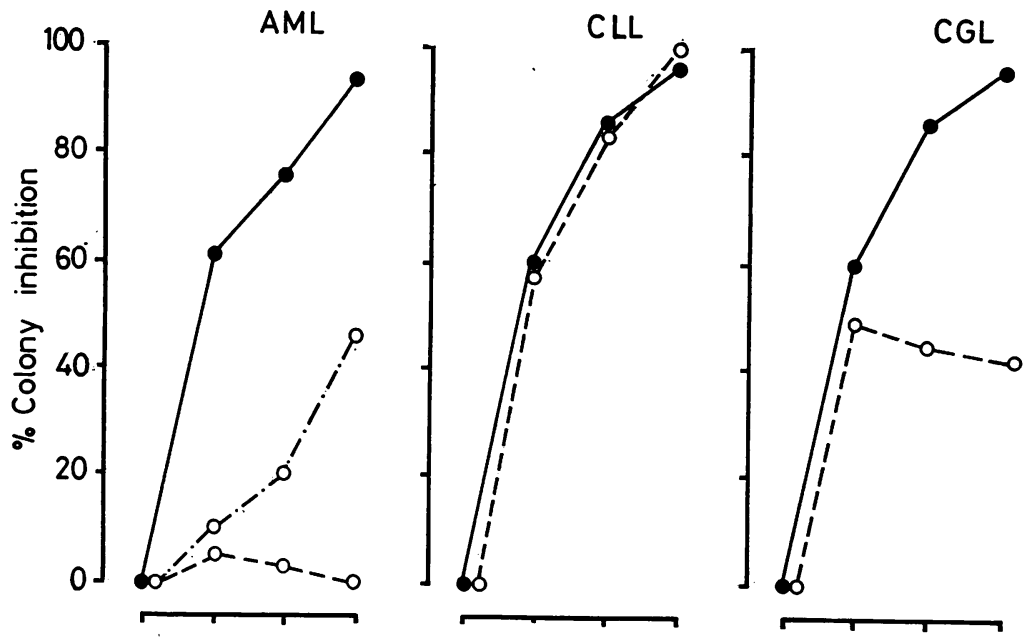

Fig. 5 Effect of prior absorption of ALG 2 on CFU inhibition and

lymphocytotoxicity. Absorbed and unabsorbed sera were tested in parallel on bone marrow samples.

Lymphocytotoxicity represents mean results obtained using lymphocytes from four normal subjects.

$\longrightarrow$ unabsorbed $A L G$; ○- - $\bigcirc$ ALG absorbed with $10^{8}$ cells/mg globulin;
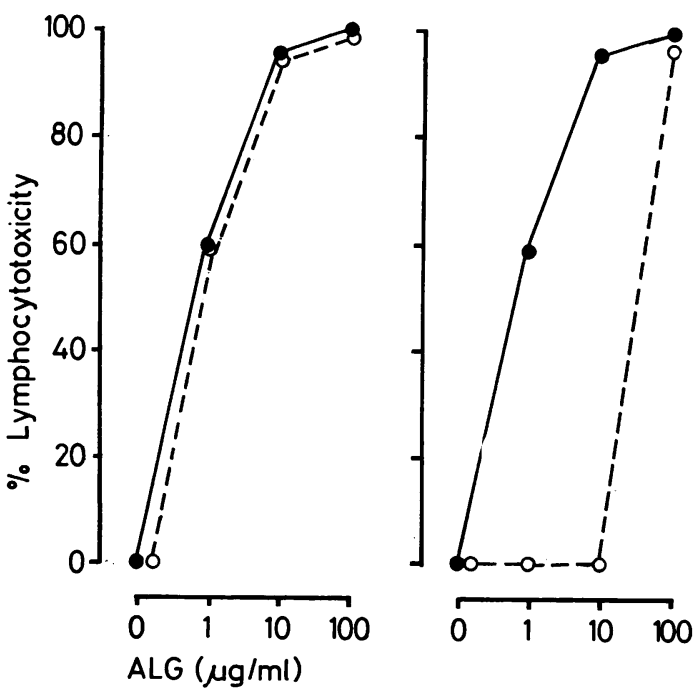

ALG $(\mu \mathrm{g} / \mathrm{ml})$

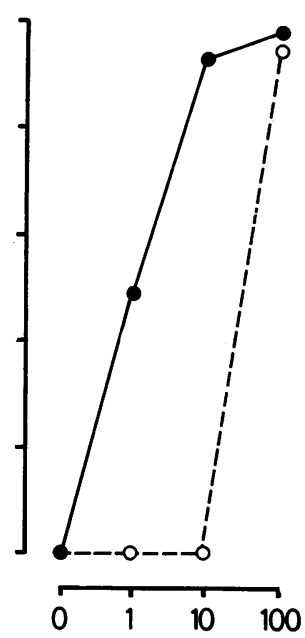

$\bigcirc-\cdot-\cdot-\bigcirc$ ALG absorbed with $10^{7}$ cells/mg globulin. same phenomenon as the stimulation of bone marrow cells by exposure for one hour to horse ATG described by Ascensão et al. (1976) in a patient with aplastic anaemia. They tentatively attributed this to inactivation of suppressor T lymphocytes by ATG, but the fact that inert horse globulin also stimulated CFU suggests that the effect may not be immunologically mediated.

The increasing inhibition seen by prolonging the incubation times of bone marrow cells with ALG suggests that the $10 \%$ autologous serum used was not potent enough to cause rapid complement mediated cell death and that prolonged incubation was necessary before CFU was irreversibly damaged.
More clear-cut results might have been obtained by using a potent rabbit complement. However, the aim of these experiments was to produce a technique for preincubation of clinical marrow graft material. Therefore we decided to restrict the foreign antigen in the system to horse globulin to avoid sensitising patients unnecessarly. ALG appeared to affect the CFU directly rather than colony stimulating-factor production by the feeder layer since (1) the effect depended on exposure of cells to ALG in the liquid phase and (2) all feeder layers were prepared at least four days in advance. Previous experiments have shown that most feeder-layer colony stimulating activity has been produced by that time. 
CFU inhibition was measurable in two ways: firstly, reduced colony number compared with control values and, secondly, reduction in the colony: cluster ratio (that is, the fall in colonies with increasing ALG concentration exceeded the fall in clusters). This suggests that partial damage to the growth of some CFU may have occurred, resulting in a cell that was capable of forming only cluster-sized groups. The enhancement by complement and the specific removal of colony inhibition by ALG absorbed on AML cells but not on CLL cells is strong evidence that inhibition was mediated by antibodies, although this has not been formally proved.

The inhibiting effect on CFU found in the serum of patients during and shortly after ALG administration indicates that significant damage to granulocyte CFU may occur in vivo, and the inhibition observed in vitro occurred at ALG concentrations that would be reached in the serum during treatment. However, the relationship of the in vitro phenomenon to possible myelosuppression caused by ALG is not clearly established. In haematologically normal individuals ALG does not cause overt bone marrow depression, although Krantz (1973) demonstrated toxicity of horse ATG to human erythroblasts and suggested that it might be responsible for the anaemia sometimes seen after treatment. On the other hand, ALG given shortly after bone marrow transplantation may prevent successful engraftment. Presumably ALG toxicity to stem cells is clinically significant only when the size of the stem cell pool is very small. Use of ALG as an immunosuppressive agent in treating patients with aplastic anaemia, as Ascensão et al. (1976) proposed, might equally cause an initial worsening of the condition.

ALG absorbed to remove stem cell toxicity would have advantages in three situations: (1) in the experimental treatment of aplastic anaemia with ALG alone, (2) in bone marrow transplantation to permit early postgraft treatment (or prophylaxis) of graft versus host disease, and (3) in the preincubation of the bone marrow graft with ALG to eliminate mature lymphocytes from the graft. This last procedure has successfully prevented graft versus host disease in incompatible donor-recipient matches in mice (Trentin and Judd, 1973) and rats (MüllerRucholz et al., 1976) and might find clinical application in situations where no fully compatible donor was available for a patient with severe aplastic anaemia. These experiments show that it is possible selectively to remove anti-CFU activity in ALG by absorption, and other studies using fetal liver cells as an absorbing antigen have produced similar results (Mosedale et al., 1976). However, there would be practical difficulties in obtaining sufficient fetal liver cells for preparing therapeutic amounts of ALG.
The possibility also remains that the removal of CFU inhibition does not correlate with any reduction in toxicity to the totipotential stem cell responsible for marrow engraftment. Antigens present on spleen CFU and not on agar CFU have been identified in the mouse (Golub, 1972), and until a human stem celf assay is available the efficacy of absorption in remov? ing anti-stem cell activity could be confirmed only byes clinical trial.

This study was supported by the Andrew Bosticw Fund, The Miriam Grenfell Leukaemia Research Trust, The Bernard Wain Fund, The University of London, and the Westminster Medical Schoow Research Trust. We thank Dr R. Roussel (Hoechsî Pharmaceuticals) and Dr J. Ivanyi (Burroughș Wellcome) for supplying the antilymphocyte globu-0 lin, and Mrs Angela Tasker for typing the manuscript. This work forms part of an MD thesis by A. $\mathbf{J}_{\vec{T}}$ Barrett.

\section{References}

Ascensão, J., Pahwa, R., Kagan, W., Hansen, J., Moore M., and Good, R. (1976). Aplastic anaemia: Evidence for an immunological mechanism. Lancet, 1, 669-671

Barrett, A. J., Humble, J. G., and Hobbs, J. R. (1975) Bone marrow suppression by antilymphocytic globulin British Medical Journal, $2,541$.

DeMeester, T. R., Anderson, N. D., and Shaffer, C. F $\stackrel{\mathbb{Q}}{\varrho}$ (1968). The effect of heterologous anti-lymphocyte serum on mouse hemopoietic stem cells. Journal of Ex윽 perimental Medicine, 127, 731-748.

Field, E. O., and Gibbs, J. E. (1968). Cross-reaction of anti-lymphocyte serum with haemopoietic stem cells:Nature, 217, 561-562.

Golub, E. S. (1972). Brain-associated stem cell antigen: an: antigen shared by brain and hemopoietic stem cells. Journal of Experimental Medicine, 136, 369-374.

Krantz, S. B. (1973). Cytotoxicity for erythroblasts in horse antihuman thymocyte gammaglobulin. Trans plantation, 16, 70-73.

Mosedale, B., Smith, M. A., and Courtenay, J. S. (1976). Preparation and characterization of antithymocyte serum and globulin without stem cell activity. Trans $=$ plantation, 22, 122-131.

Müller-Rucholz, W., Wottge, H., and Müller-Hermelink, $N$ H. K. (1976). Lymphatic tissue repopulation from syngeneic or strongly allogeneic haemopoietic stem $\mathrm{W}$ cells. (Abstract.) Experimental Haematology, 4. supplement, 94.

Pike, B. L., and Robinson, W. A. (1970). Human bone्ष्त marrow colony growth in agar gel. Journal of Cellular? Physiology, 76, 77-84.

Rodt, H., Netzel, B., Brehm, G., and Thierfelder, S (1974). Production of antibodies specific for humand thymus-derived lymphocytes purified from antibodies $\frac{\rho}{\phi}$ cross-reacting with colony-forming cells. Blut, 29, 416422. 
Storb, R., Gluckman, E., Thomas, E. D., Buckner, C. D., Clift, R. A., Fefer, A., Glucksberg, H., Graham, T. C., Johnson, F. L., Lerner, K. G., Neiman, P. E., and Ochs, H. (1974). Treatment of established human graftversus-host disease by antithymocyte globulin. Blood,
44, 57-75.

Trentin, J. J., and Judd, K. P. (1973). Prevention of acute graft-versus-host mortality with spleen-absorbed antithymocyte globulin. Transplantation Proceedings, 5, 865-868.

\section{Reports and Bulletins prepared by the Association of Clinica 1Biochemists}

The following reports and bulletins are published by the Association of Clinical Biochemists. They may be obtained from The Publishing Department, British Medical Journal (ACB Technical Bulletins), B.M.A. House, Tavistock Square, London WC1H 9JR. Overseas readers should remit by British Postal or Money Order.

SCIENTIFIC REPORTS (price $£ 1 \cdot 00 / \$ 2.00$ each)

3 Automatic dispensing pipettes: an assessment of 35 commercial instruments September 1967 P. M. G. BROUGHTON, A. H. GOWENLOCK, G. M. WIDDOWSON, and K. A. AHLQUIST

4 An evaluation of five commercial flame photometers suitable for the simultaneous determination of sodium and potassium March 1970 P. M. G. BROUGHTON and J. B. DAWSON

SCIENTIFIC REVIEWS (price $£ 1 \cdot 00 / \$ 2.00$ each)

1 The assessment of thyroid function March 1971 F. V. FLYNN and J. R. HOBBS

2 Renal function tests suitable for clinical practice January 1972 F. L. MITCHELL, N. VEALL, and R. W. E. WATTS

3 Biochemical tests for the assessment of fetoplacental function May 1975 C. E. WILDE and R. E. OAKEY

4 Test of exocrine pancreatic function March 1977 A. H. GOWENLOCK

TECHNICAL BULLETINS (price $£ 1 \cdot 00 / \$ 2.00$ each)

9 Determination of urea by AutoAnalyzer November 1966 RUTH M. HASLAM

11 Determination of serum albumin by AutoAnalyzer using bromocresol green October 1967 B. E. NORTHAM and G. M. WIDDOWSON

13 An assessment of the Technicon Type II Sampler Unit March 1968 B. C. GRAY and G. K. MCGOWAN

14 Atomic absorption spectroscopy: an outline of its principles and a guide to the selection of instruments May 1968 J. B. DAWSON and P. M. G. BROUGHTON

15 A guide to automatic pipettes (2nd edition) June 1968 P. M. G. BROUGHTON

16 A guide to automation in clinical chemistry May 1969 P. M. G. BROUGHTON

17 Flame photometers: a comparative list of 17 instruments readily available in Britain August 1969 P. WILDING

19 Spectrophotometers: a comparative list of low-priced instruments readily available in Britain May 1970 C. E. WILDE and P. SEWELL

20 Quantities and units in clinical biochemistry June 1970 P. M. G. BROUGHTON
21 Filter fluorimeters: A comparative list of 18 instruments September 1970 H. BRAUNSBERG and S. S. BROWN

22 Bilirubin standards and the determination of bilirubin by manual and technicon AutoAnalyzer methods January 1971 BARBARA BILLING, RUTH HASLAM, and N. WALD

23 Interchangeable cells for spectrophotometers and fluorimeters September 1971 S. S. BROWN and A. H. GOWENLOCK

24 Simple tests to detect poisons March 1972 B. W. MEADE et al.

25 Blood gas analysers May 1972 K. DixON

26 Kits for enzyme activity determination September 1972 S. B. ROSALKI and D. TARLOW

27 Assessment of pumps suitable for incorporation into existing continuous flow analytical systems November 1972 A. FLECK et al.

28 Routine clinical measurements of transferrin in human serum September 1973 K. DIXON

29 Control materials for clinical biochemistry (5th edition) September 1973 J. F. STEVENS

30 Notes on the quality of performance of serum cholesterol assays September 1973 s. S. BROWN

31 Determination of uric acid in blood and in urine July 1974 R. W. E. WATTS

32 A survey of amino acid analysers readily available in the United Kingdom September 1974 J. E. CARLYLE and P. PURKISS

33 Definitions of some words and terms used in automated analysis November 1974 A. FLECK, R. ROBINSON, S. S. BROWN, and J. R. HOBBS

34 Measurement of albumin in the sera of patients January 1975 LINDA SLATER, P. M. CARTER, and J. R. HOBBS

35 Investigation of the validity of temperature correction factors for serum aspartate and alanine transaminases March 1975 s. B. ROSALKI et al.

36 Factors influencing the assay of creatinine November 1975 J. G. H. COOK

37 A survey of enzyme reaction rate analysers readily available in the United Kingdom July 1977 R. A. SAUNDERS and R. F. BURNS 